\title{
Murine Double Nullizygotes of the Angiotensin Type 1A and 1B Receptor Genes Duplicate Severe Abnormal Phenotypes of Angiotensinogen Nullizygotes
}

\author{
Shinya Tsuchida, ${ }^{\star}$ Taiji Matsusaka, ${ }^{\star \ddagger}$ Xiangmei Chen, ${ }^{\star}$ Soichiro Okubo, ${ }^{\star}$ Fumio Niimura, ${ }^{\star}$ Hideki Nishimura, ${ }^{\star}$ Agnes Fogo, ${ }^{\star \S}$ \\ Hirotoshi Utsunomiya,, Tadashi Inagami, $\|$ and lekuni Ichikawa*‡ \\ $*$ Department of Pediatrics, ${ }^{\ddagger}$ Department of Medicine, ${ }^{\S}$ Department of Pathology, and $\|^{\|}$Department of Biochemistry, Vanderbilt University \\ Medical Center, Nashville, Tennessee 37232-2584
}

\begin{abstract}
Rodents are the unique species carrying duplicated angiotensin (Ang) type 1 (AT1) receptor genes, Agtr1a and Agtr1b. After separately generating Agtr1a and Agtr1b null mutant mice by gene targeting, we produced double mutant mice homozygous for both Agtr1a and Agtr1b null mutation (Agtr1a-I-; Agtr1b-I-) by mating the single gene mutants. Agtrla-I-, Agtr1b-I- mice are characterized by normal in utero survival but decreased ex utero survival rate. After birth they are characterized by low body weight gain, marked hypotension, and abnormal kidney morphology including delayed maturity in glomerular growth, hypoplastic papilla, and renal arterial hypertrophy. These abnormal phenotypes are quantitatively similar to those found in mutant mice homozygous for the angiotensinogen gene $(A g t-l-)$, indicating that major biological functions of endogenous Ang elucidated by the abnormal phenotypes of $A g t-I-$ are mediated by the AT1 receptors. Infusion of Ang II, AT1 blockers, or an AT2 blocker was without effect on blood pressure in Agtr1a-I-; Agtr1b-I- mice, indicating that AT2 receptor does not exert acute depressor effects in these mice lacking AT1 receptors. Also, unlike Agt-Imice, some Agtr1a-I-; Agtr1b-I- mice have a large ventricular septum defect, suggesting that another receptor such as AT2 is functionally activated in Agtr1a-/-, Agtr1b-I- mice. (J. Clin. Invest. 1998. 101:755-760.) Key words: gene targeting • angiotensin type 2 receptor • blood pressure $\bullet$ kidney $\bullet$ heart
\end{abstract}

\section{Introduction}

Numerous studies have suggested that angiotensin (Ang) ${ }^{1}$ has a large repertoire of biological actions $(1,2)$. Recently, mutant

Address correspondence to Iekuni Ichikawa, M.D., Ph.D.,Vanderbilt University Medical Center, MCN C4204, 21st and Garland Avenue, Nashville, TN 37232-2584. Phone: 615-322-7931; FAX: 615-322-7929; E-mail: iekuni.ichikawa@mcmail.vanderbilt.edu

Received for publication 1 October 1997 and accepted in revised form 18 December 1997.

J. Clin. Invest.

(c) The American Society for Clinical Investigation, Inc. 0021-9738/98/02/0755/06 \$2.00

Volume 101, Number 4, February 1998, 755-760

http://www.jci.org strains of mice have been engineered that are selectively and completely devoid of angiotensinogen, the Ang precursor (3-5). These angiotensinogen null mutant $(\mathrm{Agt}-\mathrm{l}-)$ mice were uniformly found to have several abnormal phenotypes, including severe hypotension, growth retardation, renal arterial wall thickening, and hypoplastic papilla. The findings establish the notion that Ang is essential for achieving normal blood pressure, normal somatic growth, and normal renal architecture. Of the two distinctive Ang receptors that are genetically characterized, angiotensin type 1 receptor (AT1) is believed to transduce most classically recognized actions of Ang $(2,6,7)$, although the function of the type 2 (AT2) receptor which was most recently identified $(8,9)$ has not been fully delineated. A hurdle in studying the biology of Ang is the difficulty in demonstrating its receptor within certain tissues. In fact, visual demonstration of Ang II receptor on the peripheral resistance vessels where Ang exerts its well-recognized vasoconstrictor action has heretofore been unsuccessful. It is entirely conceivable, therefore, that other functionally significant Ang receptors exist that are yet to be discovered.

In recent years, investigators (including ourselves) generated mouse strains that carry null mutated Ang receptor genes (i.e., Agtr1 a, Agtr1b, and Agtr2; 10-15). Of note, only mice and other rodents have these duplicated AT1 genes $(16,17)$, whereas other mammals studied thus far have a single AT1 gene (18). To our surprise, none of these murine Ang receptor gene mutants, including Agtrla null mutants, display the severely abnormal anatomical and hemodynamic phenotypes that are documented in $A g t-1-$ mice. The observations are even more puzzling in view of the fact that AT1A receptors predominate by far over AT1B receptors in mice $(19,20)$, and that Agtr1b null mutants have no identifiable abnormal phenotype (11). The results raised the possibility that, contrary to prevailing belief, Ang receptors other than AT1 or AT2 play a vital role in transducing Ang's actions on blood pressure, somatic growth, and renal architecture. It is also possible that inactivation of a specific Ang receptor leads to activation of the others in a compensatory manner, thereby minimizing manifestation of abnormal phenotypes $(19,21)$. In the present study, we generated a mutant strain of mice in which both AT1 isoform genes, Agtrla and Agtr1b, are concurrently null mutated (AT1 double nullizygotes). By examining these mutant mice parallel to $A g t-/-$ mice, we found that AT1 double nullizygotes duplicate qualitatively and quantitatively the

1. Abbreviations used in this paper: Ang, angiotensin; AT1, angiotensin type 1; AT2, angiotensin type 2; i.d., inner diameter; o.d., outer diameter. 
same abnormal phenotypes as those described for $A g t-/-$ mice (4).

\section{Methods}

Generation of mice lacking both $A T 1 A$ and $A T 1 B$ receptors. Earlier, we generated homozygous angiotensin type 1A (AT1A) receptor gene null mutant (Agtrla-/-) mice and homozygous angiotensin type 1B (AT1B) receptor gene null mutant $($ Agtr1b-/-) mice (10, $11)$. In each gene mutation study, AT1A or AT1B receptor gene was inactivated by insertion of $L a c Z$ so that $L a c Z$ instead of Agtrla or $A g \operatorname{tr} 1 b$ is driven by the respective native promoter.

In the process of generating mice lacking both AT1A and AT1B receptors, we first mated F1 heterozygous Agtrla null mutant ( $A$ gtrla $+/-$ ) males with F3 homozygous Agtr1b null mutant (Agtr1b-/-) females. This cross-mating produced double heterozygous null mutant $($ Agtrla $+/-;$ Agtrlb $+/-)$ mice. These double heterozygous mice were then mated with each other to produce mice carrying the genotype +/+, Agtrla+/-; Agtr1b-/- or Agtrla-/-; Agtr1b+/-. Finally, mice +/+, Agtr1a+/-, Agtr1b-/- or Agtr1a-/-; Agtr1b +/- were mated with mice of the same genotype to produce mice with the genotype $+/+$, Agtr1a-I-; Agtr1b-/- or other genotypes. These final products were subjected to the analyses described below. The embryonic stem cell line (E14.1) used to generate these mice was derived from strain 129/Ola. Chimeric males were crossed with C57BL/6 females so that these double mutants carry the genetic background of 129/Ola and C57BL/6 strains. The Agtr1a and Agtr1b genotypes were determined by Southern blot analysis of DNA isolated from tail biopsies $(10,11)$.

Angiotensinogen null mutant $(\mathrm{Agt}-/-)$ mice were also generated earlier in our laboratory (4). Their offspring (F4-5 generation) with the genetic background of 129/Ola and C57BL/6 strains were also subjected to the analyses described below.

Blood pressure measurement. Conscious arterial blood pressure in mice aged 5-7 wk was measured $24 \mathrm{~h}$ after surgery as described elsewhere (22). Blood pressure and heart rate were continuously monitored for 20 min until they became stable in a quiet and unrestrained environment.

To study the effect of losartan (Merck, West Point, PA), CV 11974 (Takeda Pharmaceutical Co., Osaka, Japan), PD 123319 (Research Biochemicals Inc., Natick, MA), and saralasin (Sigma Chemical Co., St. Louis, MO) on baseline blood pressure, mice at 6-10 wk of age were anesthetized with Inactin $(100 \mathrm{mg} / \mathrm{kg}$ body wt i.p.; BYK, Konstanz, Germany). The left carotid artery and right jugular vein were then cannulated with PE10 tubing for measurement of arterial pressure and drug injection. After the equilibration period, the mice received a bolus injection of $0.9 \%$ sodium chloride solution in a volume that was identical to that during the subsequent drug injections. At 10 -min intervals thereafter, enalapril at $10 \mathrm{mg} / \mathrm{kg}$ body wt (Merck) and three doses of Ang II (0.1, 1 , and $10 \mu \mathrm{g} / \mathrm{kg}$ body wt) were intravenously administered in succession. To explore the possibility of nonAT1A/non-AT1B receptors in affecting the blood pressure of Agtrla-/-, Agtrlb-/- mice, losartan (10 and $100 \mathrm{mg} / \mathrm{kg}$ body wt), CV 11974 (0.5 and $5 \mathrm{mg} / \mathrm{kg}$ body wt) or PD 123319 (10 and $30 \mathrm{mg} / \mathrm{kg}$ body wt) was given before enalapril pretreatment. Changes in mean arterial pressure after injection of saline $0.1,1$, and $10 \mu \mathrm{g} / \mathrm{kg}$ body wt of Ang II were assessed at $60 \mathrm{~s}$ based on a pilot study revealing that maximum response occurs at $\sim 60 \mathrm{~s}$. Enalapril was administered to reduce desensitized response to exogenous Ang II due to high endogenous Ang II $(19,21)$.

Histological analysis. Organs were fixed in $4 \%$ buffered paraformaldehyde, routinely processed, embedded in paraffin, and sectioned. Kidney morphology was studied by $3 \mu \mathrm{m}$-thick coronal sections including the papilla stained with periodic acid Schiff. The coronal section of kidneys were traced with the aid of camera lucida attachment, and the diameter of papilla and maximum calyceal space were measured using a National Institutes of Health Image program.
For studies of vascular morphology, cross-sections of all the interlobular and arcuate arteries were traced and examined morphometrically. Both inner and outer diameters (i.d., o.d.) were measured for each artery, and o.d.-i.d. and (o.d.-i.d.)/o.d. (designated as arterial wall thickness and wall thickness ratio, respectively; 10), were calculated and compared among wild-type, Agtrla-/-, Agtrla-/-; Agtrlb-/-, and $A g t-/-$ mice. The glomerular maturity index was calculated for each animal as described elsewhere (1-3 scale; 4$)$.

AT1 gene activity by $\beta$-galactosidase staining. Tissues from $+/+$ and Agtr1a-l-; Agtr1b-/- mice were fixed in 4\% buffered paraformaldehyde and stained with $1 \mathrm{mg} / \mathrm{ml}$ Bluo-Gal (GIBCO BRL, Gaithersburg, MD) for three days at $37^{\circ} \mathrm{C}$ as previously described in detail $(10,11,19)$.

Statistical analysis. Data are presented as means \pm SE. Statistical significance was assessed by using Mann-Whitney test and ANOVA followed by Tukey post hoc tests for multiple comparisons. Genotype frequencies were compared with expected Mendelian proportions by chi-square $\left(\chi^{2}\right)$. Differences were considered statistically significant at $P<0.05$.

\section{Results}

Generation of mice lacking both $A T 1 A$ and $A T 1 B$ receptors

To determine the survival of Agtrla-/-; Agtr $1 b-/-$ mice, we examined pups from the cross-matings between Agtrla-/-; Agtr1b+/- mice or between Agtrla+/-; Agtr1b-/- mice, which yielded more than 100 weanlings. There were no significant deviations from the prediction by Mendelian law with regard to the genotype frequency among weaned pups with the genotypes other than Agtrla-/-; Agtr1b-/-. However, there was a highly significant $\left(P<0.001\right.$ by $\left.\chi^{2}\right)$ decrease in the population of Agtr1a-/-; Agtr1b-/- mice (26 expected, 7 observed). We also found a high proportion of Agtrla-/-; Agtr1b-/- mice dying before weaning. Therefore, we killed 13 pups from cross-matings between Agtrla+/-; Agtr1b-/mice immediately after birth. We found the distribution of genotypes among these newborns to conform to Mendelian law (four were Agtrla+/+; Agtr1b-/-, six were Agtr1a+/-; Agtr1b-/-, three were Agtr1a-/-; Agtr1b-/-; $P>0.05$ by $\left.\chi^{2}\right)$. Thus, concurrent inactivation of AT1A and AT1B receptors is compatible with survival in utero, but inactivation of these receptors markedly decreases survival ex utero. Body weight gain after birth was slow in Agtrla-/-; Agtr 1b-/mice as previously reported in $A g t-/-$ mice (4).

\section{Baseline blood pressure in conscious and anesthetized animals}

Baseline mean arterial blood pressure in conscious animals averaged 106 $3,72 \pm 5$, and $72 \pm 3 \mathrm{mmHg}$ in $+/+(n=8)$, Agtrla-l-; Agtr1b-/- $(n=6 ; P<0.05$ vs $+/+)$, and Agt $-/-$ $(n=5 ; P<0.05$ vs. $+/+)$ mice, respectively. Baseline mean arterial blood pressure under anesthesia with inactin was on average $96 \pm 5,42 \pm 3$, and $45 \pm 4 \mathrm{mmHg}$ in $+/+(n=7)$, Agtrla $-/-$; Agtr1b-/- $(n=8 ; P<0.001$ vs. $+/+)$, and Agt $-/-(n=4$; $P<0.001$ vs. $+/+)$ mice, respectively.

\section{Blood pressure response to Ang II, losartan, CV 11974, PD 123319 and saralasin infusion}

Bolus injections of Ang II at $0.1,1$, and $10 \mathrm{ng} / \mathrm{kg}$ body wt after enalapril pretreatment did not cause any responses in the anesthetized Agtrla-/-; Agtrlb-/- mice (Fig. 1, $A$ and $B$ ), while bolus injections of Ang II to wild-type and Agtrla-/- mice induced a dose-dependent increase in arterial pressure. Of note, AT1 receptor antagonists (losartan, CV 11974), an AT2 receptor antagonist (PD 123319), or Ang II analogue (saralasin) was 


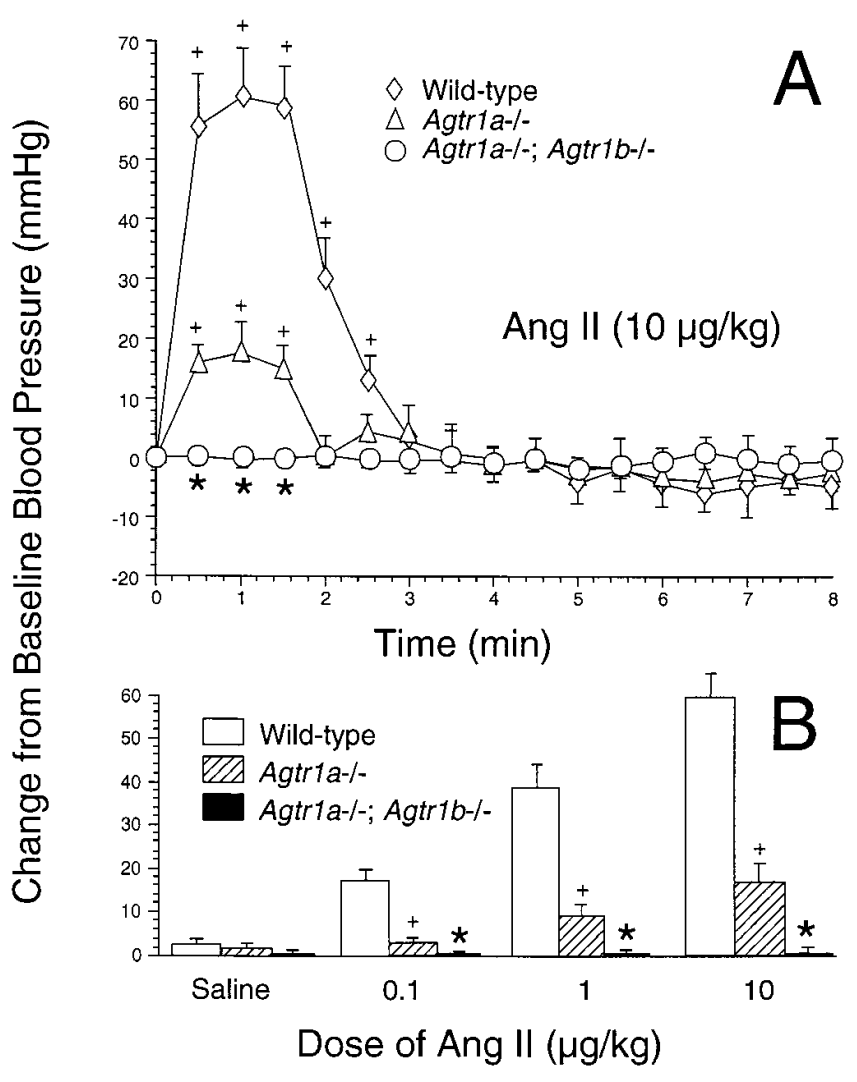

Figure 1. (A) Effect of intravenous bolus infusion of Ang II $(10 \mu \mathrm{g} / \mathrm{kg}$ Bwt) on mean arterial pressure in anesthetized mice pretreated with enalapril. Changes in mean arterial pressure from baseline assessed at $30 \mathrm{~s}$ intervals are depicted for wild-type $(n=5)$, Agtr1a-l- $(n=4)$, and Agtr1a-1-; Agtr $1 b-/-(n=4)$ animals ( $P P<0.001$ vs. wildtype and Agtrla-l-. ${ }^{+} P<0.001$ vs. baseline blood pressure). (B) changes in mean arterial pressure assessed $60 \mathrm{~s}$ after injection of saline, $0.1,1$, and $10 \mu \mathrm{g} / \mathrm{kg}$ body wt of Ang II in wild-type $(n=5)$, Agtr1a-/- $(n=4)$, and Agtr1a-/-; Agtr 1b-/- $(n=4)$ mice pretreated with enalapril. Data are expressed as means \pm SE $(* P<0.001$ vs. wild-type and $A g t r 1 a-/-.{ }^{+} P<0.001$ vs. wild-type).

without effect on blood pressure in Agtrla-/-; Agtr1b-/mice ( $n=5$ for each, data not shown), indicating that nonAT1A/non-AT1B receptors exert no acute pressor or depressor effect on arterial pressure in these mutant mice lacking AT1A and AT1B (i.e., AT1) receptors.

\section{Histological findings}

Kidney. As shown in Fig. 2 and Fig. 5 A, kidneys from AT1 double nullizygotes at $0,1,3,5$, and 9 wk of age showed progressive changes in the papilla and calyx that are similar to those described for Agt-/- mice (4). AT1 double nullizygotes had a widening calyx space (calyx-to-papilla diameter ratio, $1.57 \pm 0.21$ in $+/+$ vs. $1.75 \pm 0.23$ in Agtr1a-/-; Agtr1b-/mice at birth to $1.38 \pm 0.25$ in $+/+$ vs. $5.65 \pm 1.30$ in Agtrla $-/-$; Agtrlb-/- mice at $9 \mathrm{wk}$ of age; $P<0.001)$ and hypoplastic papilla $(0.32 \pm 0.04 \mathrm{~mm}$ in $+/+$ vs. $0.31 \pm 0.02 \mathrm{~mm}$ in Agtrla $-/-$; Agtrlb-/- mice at birth to $0.86 \pm 0.07 \mathrm{~mm}$ in $+/+$ vs. $0.30 \pm 0.09 \mathrm{~mm}$ in Agtrla-/-; Agtr1b-/- mice at 9 wk of age, $P<0.001)$.
As shown in Fig. 3, Agtr1a-/-; Agtr1b-/- mice had renal arterial lesions similar to those described for $A g t-/-$ mice; namely, prominent medial hyperplasia of the interlobular arteries and afferent arterioles. Morphometric examination of renal arteries in Agtrla-/-; Agtr1b-/- mice at 3 wk of age demonstrated a significant increase in both wall thickness $(P<$ 0.001 vs. wild-type, $P<0.01$ vs. Agtr1a-/-) and wall thickness ratio $(P<0.001$ vs. wild-type).

As in Agt-/- mice, delay in glomerular maturity was found in AT1 double nullizygotes at 1 wk of age, maturity index averaging $1.84 \pm 0.16$ in $+/+$ mice $(n=3)$ and $1.40 \pm 0.23$ in Agtrla-/-; Agtr1b-/- mice $(n=3 ; P<0.05)$. At 3 wk of age, however, the glomeruli of AT1 double nullizygotes were as mature as those in wild-type mice.

Heart. No gross anatomical deformity was recognized in Agtrla-/-; Agtrlb-/- mice $(n=37)$ when they were examined after weaning. Among the mice that died before weaning $(n=28)$, however, two Agtrla-/-; Agtr1b-/- mice were found to have a large ventricular septal defect involving both membranous and muscular portions (Fig. 4), whereas none was found in mice with the other genotypes inspected before weaning $(n=71)$.

The heart weight of animals randomly selected at birth was on average lowest in Agtrla-/-; Agtr1b-/- mice (8.8 \pm 0.4 $\mathrm{mg}, n=5)$ and highest in $+/+(9.6 \pm 0.6 \mathrm{mg}, n=6)$, although the difference did not reach statistical significance.

Adrenal glands. AT1 double nullizygotes had no gross or microscopic abnormalities in adrenal glands (Fig. 5 B).

\section{Histochemical analysis for $\beta$-galactosidase staining}

Expression of the reporter gene $L a c Z$ was systematically examined in AT1 double nullizygotes by $\beta$-galactosidase staining. In the kidney, $\beta$-galactosidase staining was most intensely observed in juxtaglomerular cells and hyperplastic renal arteries (Fig. $5 A$ ). The proximal tubule, glomerular mesangial and endothelial cells, and occasionally interstitial cells of the kid-

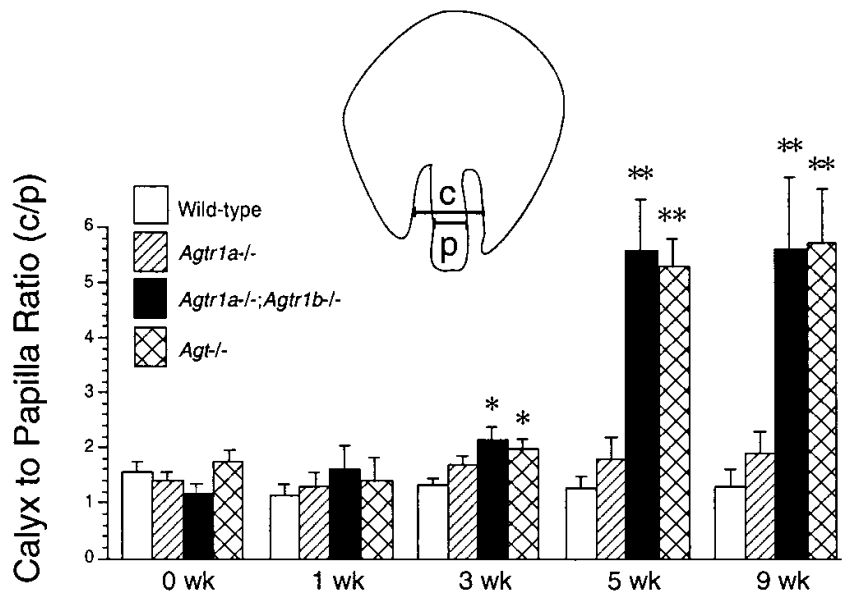

Figure 2. Calyx-to-papilla ratio studied during the first $9 \mathrm{wk}$ after birth. Values are presented as means \pm SE in wild-type $(n=6-8)$, Agtr1a-/- $(n=5-7)$, Agtr1a-/-; Agtr1b-/- $(n=4-10)$, and Agt-/( $n=3$ or 4$)$ mice. Kidneys from Agtr1a-/-; Agtr1b-/- and Agt-/mice show progressive changes of widening calyceal space and hypoplastic papilla (increasing calyx-to-papilla ratio) $(* P<0.05$ versus wild-type mice; **P<0.001 vs. wild-type and Agtr1a-/- mice). 


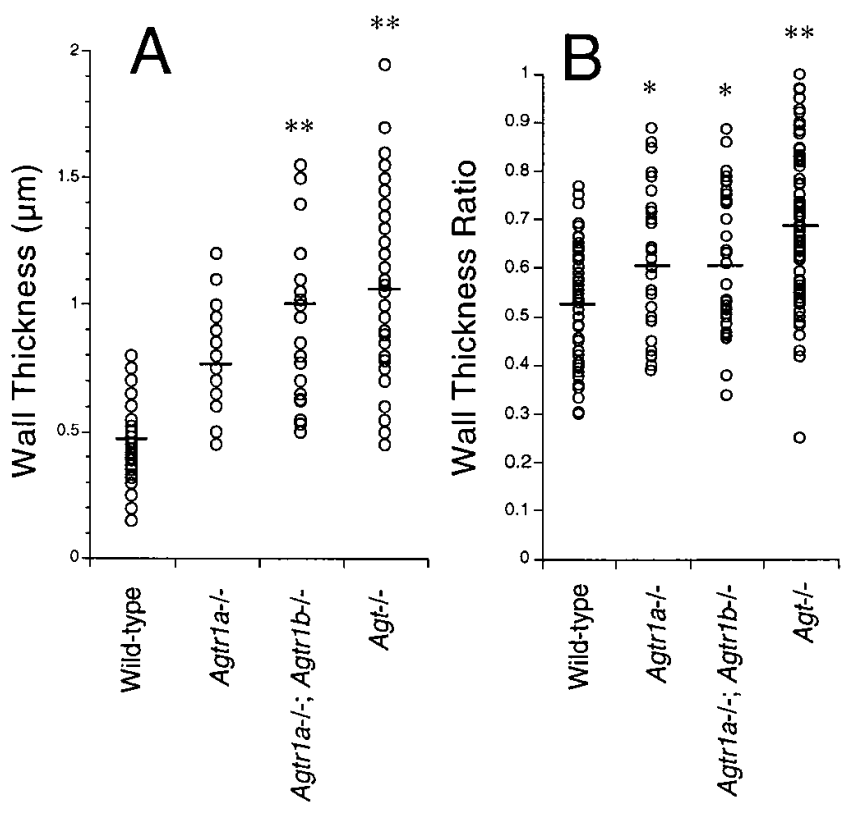

Figure 3. Morphometric analyses of renal arteries in wild-type $(n=$ 4), Agtrla-l- $(n=4)$, Agtrla-l-; Agtrlb-l- $(n=4)$, and Agt-l$(n=3)$ mice at 3 wk of age. Each dot represents a single vessel. Horizontal bars represent mean values. Arteries from Agtr1a-1-; Agtr1b-/- mice have higher values for wall thickness when compared with those of $+/+$ or Agtrla $-/-$ mice $\left({ }^{*} P<0.001\right.$ versus wildtype, $* * P<0.01$ versus wild-type and Agtr1a-/-). Values for wall thickness averaged 12.31 $\pm 0.92,19.68 \pm 1.12,25.74 \pm 1.52$, and 27.18 \pm $1.90 \mu \mathrm{m}$ in $+/+$, Agtrla-/-, Agtrla-/-; Agtr1b-/-, and Agt-/mice, respectively. (B) Arteries from Agtrla-/-; Agtrlb-/- mice reveal higher values for wall thickness ratio when compared with those of wild-type mice $\left({ }^{*} P<0.001\right.$ vs. wild-type, ${ }^{* *} P<0.001$ vs. wild-type and Agtr1a-/-). Values for wall thickness ratio averaged $0.53 \pm 0.01,0.61 \pm 0.02,0.61 \pm 0.01$, and $0.69 \pm 0.03$ in $+/+$, Agtr1a $-/-$, Agtrla-1-; Agtrlb-/-, and Agt-/- mice, respectively.

ney cortex, also showed positive staining. However, no expression was identified in the medulla or papilla of AT1 double nullizygotes of any age. In the adrenal glands, zona glomerulosa cells showed strong intensity of $\beta$-galactosidase staining within the cytosol as previously reported (11). Additionally, positive staining was visible at the cell membrane in both zona fasciculata and zona reticularis cells (Fig. $5 \mathrm{~B}$ ). In the heart, $\beta$-galactosidase staining appeared evenly distributed throughout the tissue, except that the staining was intensified within the neonatal interventricular septum (Fig. $5 C$ ). Positive staining was not clearly demonstrable in interstitial fibroblasts. In the placenta from mice at $10.5 \mathrm{~d}$ of gestation, positive staining was observed in extravillous cytotrophoblasts, whereas $\beta$-galactosidase staining was negligible within the villi or endometrium (Fig. $5 \mathrm{D}$ ). The placenta at $19 \mathrm{~d}$ of gestation showed no positive staining. $\beta$-galactosidase staining was not detectable in the lung, spleen, or peripheral resistance vessels.

\section{Discussion}

In the present study, our assessment of AT1 double nullizygotes focused on the several key functional and structural parameters that had been found to be abnormal in $A g t-1-$ mice



Figure 4. A large ventricular septal defect found in a AT1 double nullizygote that died at $2 \mathrm{~d}$ of age. Left and right lateral ventricle walls were cut open and removed with microscissors. The large septal defect is viewed from the lateral aspect. $L A$, left atrium; $L V$, left ventricle; $V S D$, ventricular septal defect.

(3-5). These are in utero and ex utero survival rates, body weight, systemic arterial pressure, heart weight, kidney morphology, particularly with regard to the maturity of the glomerulus, growth of the papilla, and renal arterial wall dimension. The analyses revealed that, unlike that of any other angiotensin receptor null mutants studied (10-15), the phenotypes of AT1 double nullizygotes duplicate those of $\mathrm{Agt}-\mathrm{I}-$ mice. The study has thus verified the notion that the AT1 receptor transduces the major biological actions of Ang II known today, and that no other receptors are required for these actions. Of all the abnormalities described above, a particularly puzzling one is the hypoplastic papilla, which becomes evident only a

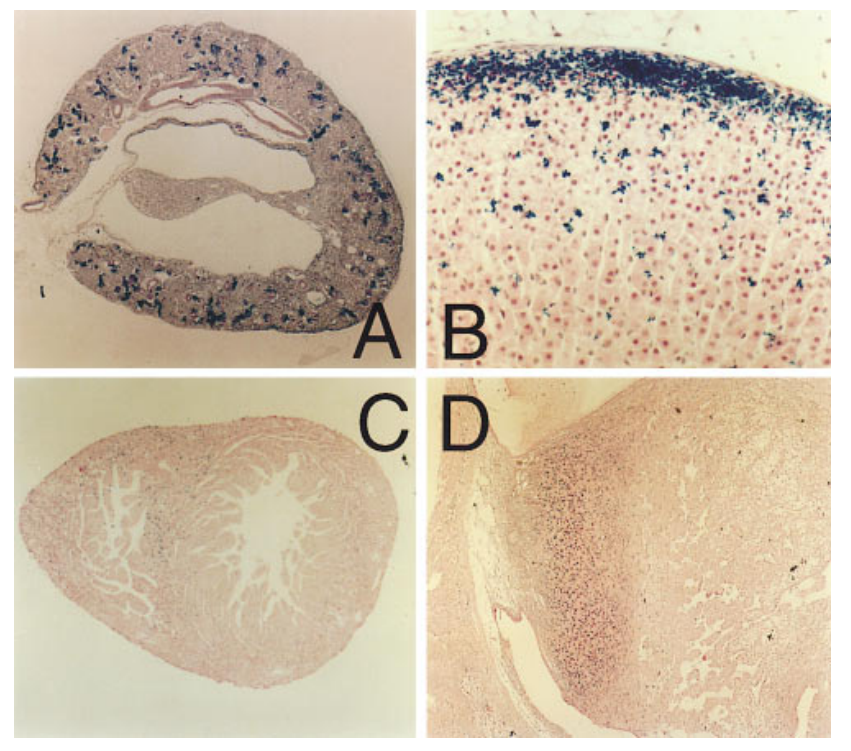

Figure 5. Tissue specimens from AT1 double nullizygotes stained for AT1 gene activity by $\beta$-galactosidase staining. $(A)$ Kidney from a 9-wk-old mouse stained with Bluo-Gal and PAS. Hypoplastic papilla is evident. $\beta$-galactosidase staining was most intensely observed in juxtaglomerular cells and hyperplastic renal arteries, and was also found in the proximal tubule, glomerular mesangial, and endothelial cells. (B) Adrenal gland from a 5-wk-old mouse stained with Bluo$\mathrm{Gal}$ and $\mathrm{H} \& \mathrm{E}$. In addition to zona glomerulosa cells, positive staining was visible in both zona fasciculata and reticularis cells. $(C)$ The heart from a newborn mouse stained with Bluo-Gal and H\&E. Positive staining was intensely observed in the interventricular septum. $(D)$ Placenta from a mouse at $10.5 \mathrm{~d}$ of gestation stained with Bluo-Gal and $\mathrm{H} \& \mathrm{E}$. Positive staining was seen in extravillous cytotrophoblasts. $A, 10 \times ; B, 335 \times ; C, 20 \times ; D, 150 \times$. 
few weeks after birth. We therefore vigorously searched for AT1 receptor gene expression in the renal medulla and papilla using a reporter gene system. Although the reporter gene could disclose the localization of the receptor within finite structures of several organs including the placenta and adrenal and renal cortex, no expression was identified in the medulla or papilla. Results of our previous study using in situ hybridization with the antisense cRNA probe for the AT1 receptor (23) are consistent with the above results from the present study. The hypoplastic papilla seen in Agt-/- and AT1 double nullizygotes may therefore reflect an indirect effect of the inhibition of AT1 function on the renal papilla. The results from our most recent study support this possibility (24).

In addition to these abnormalities, other organs, e.g., the adrenal gland, were found to be morphologically intact in AT1 double nullizygotes as well as in $A g t-/-$ mice (22). Taken together, therefore, the results indicate that the markedly high endogenous Ang II present in AT1 double nullizygotes (19) does not exert discernible actions via non-AT1 receptors since AT1 double nullizygotes are phenotypically identical to Agt-/mice, which completely lack Ang's actions. Moreover, infusion of Ang II, AT1 blockers, or an AT2 blocker was without effect on blood pressure in Agtrla-/-; Agtr1b-/- mice, indicating that AT2 receptor, which is believed to transduce the depressor effect of Ang II (12), does not exert an acute depressor effect in the absence of AT1 receptors. It is conceivable, however, that an important role of the AT2 receptor may be demonstrable when its function is chronically inhibited.

Of interest is our additional finding that two out of 28 AT1 double nullizygotes inspected had a ventricular septum defect. This finding is in concert with the findings in humans that an abnormality in chromosome $3 \mathrm{q}$ on which the AT1 gene resides (25) accompanies a ventricular septum defect (26), although these findings may just be coincidental. Our recent demonstration of AT1 gene expression in embryonic hearts of wild-type mice (23) further supports the important ontogenic role of the AT1 receptor in the formation of ventricular septum. In this regard, lack of similar cardiac defect in $A g t-1-$ mice (4) raised the possibility that activation of non-AT1 receptor due to enhanced Ang II generation in AT1 double nullizygotes, but not in Agt-I- mice, can account for the cardiac muscle defect seen only in AT1 double nullizygotes. If this is indeed the case, the AT2 receptor that is expressed in rodent embryonic hearts (27) is one such candidate, since recent studies suggest a role of this receptor in cell apoptosis $(28,29)$.

\section{Acknowledgments}

The authors thank Mr. Edward Price, Jr., Ms. Teresa Bills, Ms. Tracy Moore-Jarrett, and Ms. Ellen Donnert for their superb technical assistance. Dr. Taiji Matsusaka is the recipient of a fellowship grant from the National Kidney Foundation. Dr. Agnes Fogo is a recipient of an Established Investigator Award from the American Heart Association.

This work was supported by National Institutes of Health grants DK-44757, DK-37868, and HL-58205.

\section{References}

1. Matsusaka, T., J. Hymes, and I. Ichikawa. 1996. Angiotensin in progressive renal diseases: theory and practice. J. Am. Soc. Nephrol. 7:2025-2043.

2. Timmermans, P.B., P.C. Wong, A.T. Chiu, W.F. Herblin, and R.D.
Smith. 1993. Angiotensin II receptors and angiotensin II receptor antagonists. Pharmacol. Rev. 45:205-251.

3. Kim, H.S., J.H. Krege, K.D. Kluckman, J.R. Hagaman, J.B. Hodgin, C.F. Best, J.C. Jennette, T.M. Coffman, N. Maeda, and O. Smithies. 1995. Genetic control of blood pressure and the angiotensinogen locus. Proc. Natl. Acad. Sci. USA. 92:2735-2739.

4. Niimura, F., P.A. Labosky, J. Kakuchi, S. Okubo, H. Yoshida, T. Oikawa, T. Ichiki, A.J. Naftilan, A. Fogo, T. Inagami, B.L.M. Hogan, and I. Ichikawa. 1995. Gene targeting reveals a requirement for angiotensin in the development and maintenance of kidney morphology and growth regulation. J. Clin. Invest. 96:2947-2954.

5. Tanimoto, K., F. Sugiyama, Y. Goto, J. Ishida, E. Takimoto, K. Yagami, A. Fukamizu, and K. Murakami. 1994. Angiotensinogen-deficient mice with hypotension. J. Biol. Chem. 269:31334-31337.

6. Sasaki, K., Y. Yamano, S. Bardham, N. Iwai, J. Murray, M. Hasegawa, Y. Matsuda, and T. Inagami. 1991. Cloning and expression of a complementary DNA encoding a bovine adrenal angiotensin II type-1 receptor. Nature. 351: 230-232.

7. Murphy, T.J., R.W. Alexander, K.K. Griendling, M.S. Runge, and K.E. Bernstein. 1991. Isolation of a cDNA encoding the vascular type-1 angiotensin II receptor. Nature. 351:233-236.

8. Kambayashi, Y., S. Bardhan, K. Takahashi, S. Tsuzuki, H. Inui, T. Hamakubo, and T. Inagami. 1993. Molecular cloning of a novel angiotensin II receptor isoform involved in phosphotyrosine phosphatase inhibition. J. Biol. Chem. 268:24543-24546.

9. Mukoyama, M., M. Nakajima, M. Horiuchi, H. Sasamura, R.E. Pratt, and V.J. Dzau. 1993. Expression cloning of type 2 angiotensin II receptor reveals a unique class of seven-transmembrane receptors. J. Biol. Chem. 268:2453924542 .

10. Matsusaka, T., H. Nishimura, H. Utsunomiya, J. Kakuchi, F. Niimura, T. Inagami, A. Fogo, and I. Ichikawa. 1996. Chimeric mice carrying 'regional' targeted deletion of the angiotensin type 1A receptor gene: Evidence against the role for local angiotensin in the in vivo feedback regulation of renin synthesis in juxtaglomerular cells. J. Clin. Invest. 98:1867-1877.

11. Chen, X., W. Li, H. Yoshida, S. Tsuchida, H. Nishimura, F. Takemoto, S. Okubo, A. Fogo, T. Matsusaka, and I. Ichikawa. 1997. Targeting deletion of angiotensin type 1B receptor gene in the mouse. Am. J. Physiol. 272:F299F304.

12. Ichiki, T., P. Labosky, C. Shiota, S. Okuyama, Y. Imagawa, A. Fogo, F. Niimura, I. Ichikawa, B. Hogan, and T. Inagami. 1995. Effects on blood pressure and exploratory behaviour of mice lacking angiotensin II type-2 receptor. Nature. 377:748-750.

13. Hein, L., G.S. Barsh, R.E. Pratt, V.J. Dzau, and B.K. Kobilka. 1995. Behavioural and cardiovascular effects of disrupting the angiotensin II type-2 receptor in mice. Nature. 377:744-747.

14. Ito, M., M.I. Oliverio, P.J. Mannon, C.F. Best, N. Maeda, O. Smithies, and T.M. Coffman. 1995. Regulation of blood pressure by the type 1A angiotensin II receptor gene. Proc. Natl. Acad. Sci. USA. 92:3521-3525.

15. Sugaya, T., S. Nishimura, K. Tanimoto, E. Tanimoto, T. Yamagishi, K Imamura, S. Goto, K. Imaizumi, Y. Hisada, A. Otsuka, et al. 1995. Angiotensin II type 1a receptor-deficient mice with hypotension and hyperreninemia. $J$. Biol. Chem. 270:18719-18722.

16. Yoshida, H., J. Kakuchi, D.F. Guo, H. Furuta, N. Iwai, R. van der Meerde Jong, T. Inagami, and I. Ichikawa. 1992. Analysis of the evolution of angiotensin II type 1 receptor gene in mammals (mouse, rat, bovine and human). Biochem. Biophys. Res. Comm. 186:1042-1049.

17. MacTaggart, T.E., M. Ito, O. Smithies, and S.W. John. 1997. Mouse angiotensin receptor genes Agtr1a and Agtr1b map to chromosomes 13 and 3. Mamm. Genome. 8:294-295.

18. Clauser, E., K.M. Curnow, E. Davies, S. Conchon, B. Teutsch, B. Vianello, C. Monnot, and P. Corvol. 1996. Angiotensin II receptors: protein and gene structures, expression and potential pathological involvements. Eur. J. Endocrinol. 134:403-411.

19. Nishimura, H., T. Matsusaka, A. Fogo, V. Kon, and I. Ichikawa. 1997. A novel in vivo mechanism for angiotensin type 1 receptor regulation. Kidney Int. 52:345-355.

20. Burson, J.M., G. Aguilera, K.W. Gross, and C.D. Sigmund. 1994. Differential expression of angiotensin receptor 1A and 1B in mouse. Am. J. Physiol. 267:E260-E267.

21. Oliverio, M., C. Best, H. Kim, W. Arendshorst, O. Smithies, and T. Coffman. 1997. Angiotensin II responses in AT (1A) receptor-deficient mice; a role for AT (1B) receptors in blood pressure regulation. Am. J. Physiol. 272: F515-F520.

22. Okubo, S., F. Niimura, H. Nishimura, F. Takemoto, A. Fogo, T. Matsusaka, and I. Ichikawa. 1997. Angiotensin-independent mechanism for aldosterone synthesis during chronic extracellular fluid volume depletion. J. Clin. Invest. 99:855-860.

23. Kakuchi, J., T. Ichiki, S. Kiyama, B.L. Hogan, A. Fogo, T. Inagami, and I. Ichikawa. 1995. Developmental expression of renal angiotensin II receptor genes in the mouse. Kidney Int. 47:140-147.

24. Miyazaki, Y., H. Nishimura, R. Harris, J. McKanna, T. Inagami, and I. Ichikawa. 1997. Angiotensin regulates embryonic development of the ureter via 
type 1 (AT1) and type 2 (AT2) receptors. J. Am. Soc. Nephrol. 8:405A.

25. Curnow, K., L. Pascoe, and P. White. 1992. Genetic analysis of the human type-1 angiotensin II receptor. Mol. Endocrinol. 6:1113-1118.

26. Wilson, G., M. Dasouki, and M. Barr. 1985. Further delineation of the dup (3q) syndrome. Am. J. Med. Genet. 22:117-123.

27. Sechi, L.A., C.A. Griffin, E.F. Grady, J.E. Kalinyak, and M. Schambelan. 1992. Characterization of angiotensin II receptor subtypes in rat heart.
Circ. Res. 71:1482-1489.

28. Yamada, T., M. Horiuchi, and V.J. Dzau. 1996. Angiotensin II type 2 receptor mediates programmed cell death. Proc. Natl. Acad. Sci. USA. 93:156-160.

29. Liu, Y.H., X.P. Yang, V.G. Sharov, O. Nass, H.N. Sabbah, E. Peterson, and O.A. Carretero. 1997. Effects of angiotensin-converting enzyme inhibitors and angiotensin II type 1 receptor antagonists in rats with heart failure. Role of kinins and angiotensin II type 2 receptors. J. Clin. Invest. 99:1926-1935. 